DOI

\title{
ДОСВІД ВИКОРИСТАННЯ ІННОВАЦІЙНИХ ТЕХНОЛОГІЙ ДЛЯ АКТИВІЗАЦІЇ ПІЗНАВАЛЬНОЇ ДІЯЛЬНОСТІ СТУДЕНТІВ ПІД ЧАС ВИКЛАДАННЯ ФАРМАКОГНОЗІЇ
}

Ж. М. Гаїна

\author{
Буковинський державний медичний університет
}

\section{THE EXPERIENCE OF INNOVATIVE TECHNOLOGIES APPLICATION OF ACTIVATION STUDENT'S LEARNING ABILITIES DURING PHARMACOGNOSY TEACHING}

\author{
Zh. M. Haiina
}

\author{
Bukovynian State Medical University
}

\begin{abstract}
У статті представлений досвід використання сучасних методів навчання (мультимедіа) при викладанні фармакогнозії студентам фармацевтичного факультету Буковинського державного медичного університету.
\end{abstract}

The article presents the experience of modern teaching methods (multimedia) during student's Pharmacognosy teaching at the Pharmaceutical Faculty of Bukovynian State Medical University.

Вступ. Впровадження мультимедійних технологій, як одного із способів активізації пізнавальної діяльності студентів, сприяє формуванню професійних знань, умінь, навичок майбутніх провізорів, поліпшенню якості освіти в цілому. Викладання теоретичного матеріалу з фармакогнозії - саме те поле діяльності сучасного викладача, де за допомогою інноваційних форм та методів навчання можливо і доцільно використовувати мультимедійні інформаційні технології. Адже фармакогнозія, як одна з профільних дисциплін фармацевтичної освіти, має важливе значення у формуванні спеціалістів-провізорів, оскільки використання препаратів рослинного та тваринного походження в сучасній медицині за останнє десятиліття значно зросло і розширилося як в Україні, так і в багатьох інших країнах.

Основна частина. Проста передача знань від того, хто навчає, до того, хто навчається, - застаріла. На допомогу викладачам прийшли сучасні методики навчання, які передбачають оптимізацію навчально-пізнавальної діяльності студентів. Іде процес заміни традиційних підходів до навчання, а саме: інформативно-ілюстративного, пасивно-споглядального принципу на активнопізнавальний, творчий [1].

(c) Ж. М. Гаїна
Як свідчать літературні джерела, нині надається перевага інноваційним методам навчання, зокрема мультимедіа, що сприяє активній пізнавальній діяльності і, відповідно, забезпечує розвиток ініціативи й активності мислення студентів [2, 3].

У руслі виконання магістерської роботи при НФаУ “Мультимедійні технології: умови і шляхи реалізації у ВНЗ” на кафедрі фармації Буковинського державного медичного університету ще в 2006/2007 н. р. проаналізовано результати анкетування студентів 3 курсу фармацевтичного факультету спеціальності “Клінічна фармація” щодо покращання успішності з фармакогнозії завдяки широкому впровадженню мультимедійних технологій у навчальний процес.

При цьому в осінньому семестрі використовувалися лише традиційні методи навчання, а у весняному всі лекції читалися з застосуванням інноваційних технологій - мультимедіа (зображення як лікарських рослин (ЛР), так і їхніх домішок, макро- та мікроскопічні ознаки ЛР та ін.).

Порівняльний аналіз успішності студентів із фармакогнозії за результатами щомісячних атестацій та контрольних підсумкових робіт засвідчив зростання середнього бала на 0,4 у весняному семестрі.

Опитування викладачів кафедри фармації виявило, що більшість з них (60%) готові до впрова- 
дження інновацій у педагогічний процес і частину лекцій читають 3 використанням мультимедійних презентацій.

У викладачів з великим стажем роботи іноді виникають труднощі психологічного (30%) або технічного (20 \%) характеру при підготовці до лекції, в той час як молоді викладачі відчувають труднощі в самій методиці впровадження цих технологій у навчально-виховний процес (50 \%).

При анкетуванні студентів на запитання “Лекціям якої форми надаєте перевагу?” - було відмічено, що лише 13 \% опитаних студентів надають перевагу традиційній лекції, а 57 \% - лекції мультимедійною презентацією. На запитання “Чи допомогла Вам мультимедійна лекція в поглибленні знань із фармакогнозії?” позитивно відповіли 61 \% студентів, негативно - $18 \%$.

Таким чином, впровадження ще в 2006/2007 н. р. мультимедійних технологій у навчальний процес сприяло підвищенню як пізнавального інтересу у студентів, так і рівня їх знань із дисципліни.

Отриманий майже 10-річний досвід використання інноваційних технологій, зокрема і мультимедіа, при викладанні фармакогнозії студентам фармацевтичного факультету свідчить про збільшення обсягу самостійного опрацювання інформації студентами.

Також інформаційні технології забезпечують одну з найважливіших педагогічних умов навчання, на якій наголошують психологи і педагоги, багатоканальність і полімодальність сприйняття інформації.

Комп’ютеризація процесу викладання фармакогнозії дозволяє індивідуалізувати процес навчання за рахунок більш повного врахування психофізіологічних особливостей кожного студента. Адже індивідуальне сприйняття інформації створює максимальні можливості для прояву ініціативи, самостійності і творчості особистості та забезпечення якісного контролю навчально-пізнавальної діяльності студентів [4, 5].

\section{Список літератури}

1. Вища освіта України - європейський вимір: стан, проблеми, перспективи // Вища школа. - 2008. - № 6. - С. 88-125.

2. Бичков О. О. До проблеми оптимізації навчального процесу в сучасних умовах використання мультимедійних технологій / О.О.Бичков // Нові технології навчання. Науково-методичний збірник. - К. : Науково-
У Буковинському державному медичному університеті, забезпечуючи позааудиторну самостійну роботу студентів із вільним доступом до навчальнометодичних матеріалів, ще в 2011 році запроваджена система управління навчанням MOODLE.

Мультимедійні технології системи MOODLE (Modular Object Oriented Dynamic Learning Environment) дають можливість викладачам, зокрема викладацькому складу кафедри фармацевтичної ботаніки та фармакогнозії, використовувати сучасні досягнення педагогічної науки для збагачення наочного матеріалу з фармакогнозії.

Ілюстрування морфологічних ознак лікарських рослин, зокрема екзотичних, результатів мікроскопічного аналізу лікарської рослинної сировини, кольорових якісних реакцій на біологічно активні речовини, відмінностей морфологічно близьких видів ЛР, схеми, таблиці, відеоматеріали - все це активізує пізнавальну діяльність студентів та дозволяє використовувати проблемний, частково-пошуковий, дослідницький тощо методи навчання.

Разом з тим, подання аудіовізуальної інформації сприяє досягненню взаємозв'язку надання теоретичної інформації студентам з практичними навичками (відображення результатів мікроскопічного аналізу лікарської рослинної сировини тощо), які вони формують на практичних заняттях з фармакогнозії [6]. У підсумку підвищується рівень навчання студентів. Адже за даними ЮНЕСКО:

- при слуховому сприйнятті закріплюється 15 \% мовної інформації;

- при зоровому - 25 \% візуальної інформації;

- слухаючи та дивлячись одночасно, людина запам’ятовує 65 \% інформації.

Висновок. Отже, при вивченні фармакогнозії як профільної дисципліни, яка є невід'ємною частиною формування майбутнього спеціаліста, доцільно використовувати мультимедійні технології для активізації пізнавальної діяльності студентів, що сприяє формуванню їхніх знань, умінь, навичок, поліпшенню якості освіти.

методичний центр вищої освіти. - 2006. - Вип. 42. С. $36-43$.

3. Краснов В. В. Проблеми визначення ефективності інноваційних процесів у системі освіти / В. В. Краснов // Проблеми освіти : науково-методичний збірник. К. : Наук.-метод. центр вищої освіти, 2006. - Вип. 44. -132 c. 
4. Конюхова Н. А. Особливості організації самостійної навчально-пізнавальної діяльності студентів / Н. А. Конюхова // Теорія та методика управління освітою. -2010. - № 4. - C. 1-10.

5. Півторак К. В. Формування особистості та мотивації до навчання у студентів медичного університету / К. В. Півторак, І. В. Феджага // Медична освіта. - 2011. - № 4. - С. 28-31.
6. Програма навчальної дисципліни “Фармакогнозія” (для студентів вищого фармацевтичного навчального закладу та фармацевтичних факультетів вищих медичних навчальних закладів III-IV рівнів акредитації спеціальність “Фармація”). - К. : МОЗ України, Центральний методичний кабінет з вищої медичної освіти, 2011. -36 c.

Отримано 20.05.15 